\title{
PENINGKATAN KUALITAS LINGKUNGAN PERKOTAAN MELALUI PENGEMBANGAN RUANG TERBUKA HIJAU TERINTEGRASI IPAL KOMUNAL
}

\author{
Ingerid Lidia Moniaga \& Fela Warouw \\ Laboratorium Bentang Alam, Program Studi Perencanaan Wilayah dan Kota, Fakultas Teknik, \\ Universitas Sam Ratulangi \\ ingeridmoniaga73@gmail.com
}

\begin{abstract}
Abstrak
Kelompok Karang Taruna Bahari, merupakan salah satu kelompok sosial masyarakat yang berada di Kelurahan Tumumpa Dua Kecamatan Tuminting Kota Manado. Melalui kelompok Karang Taruna ini maka kegiatan Pengabdian Kepada Masyarakat dilakukan sebagai salah satu bentuk penyebaran informasi pengetahuan dan teknologi yang diarahkan pada penyuluhan dan pelatihan tentang praktek pengembangan ruang terbuka hijau terintegrasi sistem instalasi pengolahan air limbah komunal pada kawasan sempadan sungai Bailang Kota Manado. Target luaran yang ingin dicapai pada pembinaan dan pendampingan kelompok Karang Taruna Kelurahan Tumumpa Dua yaitu : (1)terciptanyan sumberdaya manusia yang peduli terhadap kualitas lingkungan permukiman melalui sarana sanitasi dan ruang publik, (2) terciptanya sistem integrasi IPAL Komunal dan Ruang Terbuka Hijau (RTH) di lingkungan permukiman padat penduduk, (3) pengembangan ruang terbuka hijau di lingkungan permukiman dengan penanaman tanaman-tanaman dalam pot untuk menciptakan ruang estetika.
\end{abstract}

Kata Kunci: RTH, IPAL komunal, ruang publik.

\section{PENDAHULUAN}

\section{Analisis Situasi}

Perkembangan pembangunan suatu kota tidak pernah lepas dari campur tangan masyarakatnya. Masyarakat kota atau wilayah mempunyai peran yang sangat penting dalam pembangunan. Peran serta dan partisipasi masyarakat dalam mewujudkan kota yang bersih dan berwawasan lingkungan perlu ditunjang oleh berbagai komponen masyarakat diantaranya melalui kelompok-kelompok masyarakat seperti kelompok Karang Taruna. Pengelolaan lingkungan yang baik akan menciptakan suatu lingkungan pemukiman yang baik pula. Upaya pengelolaan ini dilakukan dengan melibatkan pemerintah dan penggerak masyarakat atau kelompok Karang Taruna yang didukung oleh partisipasi masyarakat setempat. Hal ini dikarenakan organisasi komunitas spasial lingkungan pemukiman masih lebih banyak berperan, sebagai perpanjangan tangan birokrasi. Akan tetapi, tanpa adanya faktor penggerak masyarakat, pengelolaan kebersihan lingkungan masih dapat dilaksanakan jika masing-masing anggota komunitas mempunyai kesadaran terhadap lingkungan. Sebagai contoh, menjaga kebersihan lingkungan melalui tata hijau sebagai upaya meningkatkan kualitas lingkungan, pengelolaan sampah, dan sanitasi lingkungan masih perlu pendampingan dan pembinaan melalui kegiatan-kegiatan sosialisasi berupa penyuluhan dan pelatihan. 
Permasalahan yang muncul pada kelompok Karang Taruna ini yaitu belum adanya sosialisasi tentang pengembangan ruang terbuka hijau di lingkungan permukiman padat penduduk sebagai upaya mengatasi iklim mikro dan estetika lingkungan di Kelurahan Tumumpa Dua lingkungan 4 Kota Manado. Melalui kelompok Karang Taruna ini maka kegiatan Pengabdian Kepada Masyarakat dilakukan sebagai salah satu bentuk penyebaran informasi pengetahuan dan teknologi yang diarahkan pada penyuluhan dan pelatihan tentang praktek pengembangan ruang terbuka hijau terintegrasi sistem instalasi pengolahan air limbah komunal, dan sistem pengelolaan persampahan pada kawasan sempadan sungai Bailang Kota Manado.

\section{Target dan Luaran}

Target luaran yang ingin dicapai pada pembinaan dan pendampingan kelompok Karang Taruna Kelurahan Tumumpa Dua yaitu:

a. Terciptanyan sumberdaya manusia yang peduli terhadap kualitas lingkungan permukiman melalui sarana sanitasi dan ruang publik;

b. Terciptanya sistem integrasi IPAL Komunal dan Ruang Terbuka Hijau (RTH) di lingkungan permukiman padat penduduk; dan

c. Pengembangan ruang terbuka hijau di lingkungan permukiman dengan penanaman tanaman-tanaman dalam pot untuk menciptakan nilai estetika lingkungan.

\section{KAJIAN TEORI \\ Makna Ruang Publik di Lingkungan Permukiman}

Ruang Publik ialah ruang terbuka yang dapat menampung aktivitas manusia secara bersama-sama (komunal), sebagai tempat berinteraksi dan menjalin hubungan sosial-budaya masyarakat. Pemerintah bertanggung jawab dalam menyediakan ruang publik kepada masyarakat secara gratis dan masyarakat berhak untuk memanfaatkan dan menikmati keberadaan ruang publik. Semua lapisan masyarakat berhak untuk mendapatkan layanan berupa ketersediaan ruang publik yang layak. Salah satu komponen masyarakat yang ada di perkotaan adalah masyarakat permukiman padat penduduk yang juga berhak untuk mendapatkan akses layanan tersebut. Permasalahan yang sering muncul pada permukiman padat penduduk di wilayahwilayah perkotaan yakni ketidakteraturan bangunan, sarana sanitasi yang buruk, ketersediaan air bersih yang terbatas, tidak tersedianya ruang publik seperti ruang terbuka hijau untuk aktivitas warga. Keterbatasan-keterbatasan tersebut akibat terbatasnya lahan yang tersedia pada permukiman yang padat penduduk.

Pentingnya ruang publik di lingkungan permukiman menurut Darmawan, 2009 antara lain: a) memberikan makna 
atau arti bagi masyarakat setempat secara individual maupun kelompok (meaningful), b) tanggap terhadap semua keinginan pengguna dan dapat mengakomodir kegiatan yang ada pada ruang publik tersebut (responsive), c) menerima kehadiran berbagai lapisan masyarakat dengan bebas tanpa ada diskriminasi (democratic). Segenap masyarakat dapat memanfaatkan ruang publik untuk segala macam kegiatan baik individual atau berkelompok. Permasalahan ruang publik secara umum yang sering tidak dipikirkan dalam perencanaan yakni perawatan dan pengelolaannya. Desain ruang-ruang publik yang dirancang dengan penekanan estetika bentuk yang rumit akan menyulitkan dalam perawatan, sehingga sistem pengelolaannya perlu dipikirkan. Karena selama ini semua ruang publik dibebankan pada pemerintah.
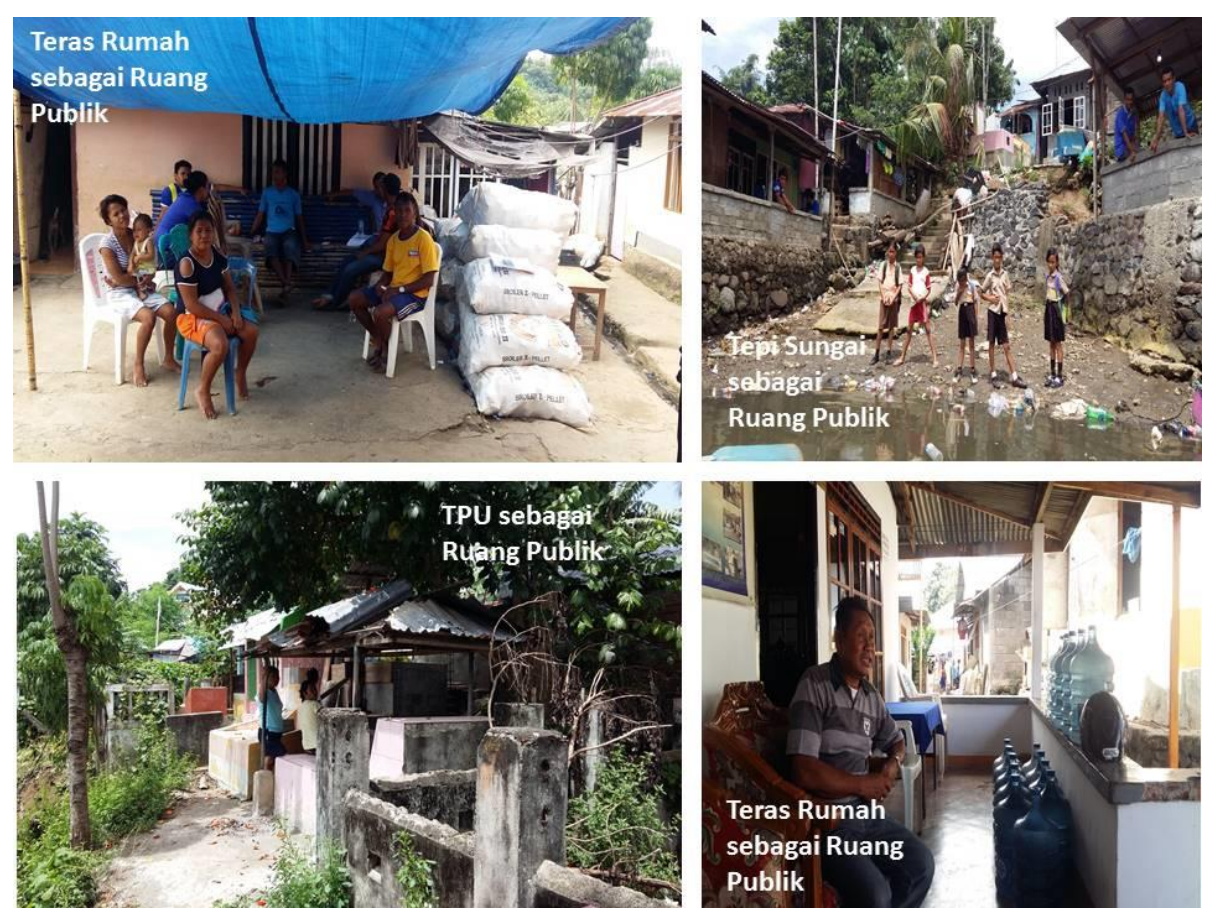

Gambar 1. Identifikasi Ruang Publik di Kelurahan Tumumpa Dua Lingkungan 4

Metode pengelolaan ruang publik yang perlu dikembangkan yakni metode kemitraaan bersama masyarakat untuk berpartisipasi aktif dalam pengelolaannya. Anita, J dkk (2012), dalam penelitiannya menguraikan miskinnya ruang publik yang dapat menampung berbagai aktivitas bersama dikhawatirkan terjadinya berbagai masalah sosial kemasyarakatan sebagai akibat dari kurangnya kebersamaan dan sosialisasi antar warga. Masyarakat tidak lagi memiliki ruang bersama untuk saling berinteraksi, komunikasi antar warga, anakanak tidak lagi memiliki tempat bermain di ruang luar, sehingga budaya kebersamaan dan toleransi semakin terkikis. Melalui kegiatan IbM ini hasil identifikasi ruang publik di lokasi kelurahan Tumumpa Dua Lingkungan 4 terdapat pada gang-gang, teras depan rumah, tepi sungai, dan tempat 
pemakaman umum (TPU). Hal tersebut akibat terbatasnya lahan dan kurang pahamnya masyarakat akan makna ruang publik. Namun dari hasil identifikasi diperoleh gambaran bahwa masyarakat membutuhkan ruang publik sebagai ruang bersama tempat masyarakat bersantai, beristirahat, dan bersosialisasi sesuai kondisi sosial-kultural masyarakat yang sebagian besar bermata pencaharian sebagai nelayan tradisional dan etnis sangihe. Kondisi tersebut dapat dilihat pada gambar 1.

\section{Pengembangan RTH dalam}

\section{Peningkatan Kualitas Lingkungan}

\section{Permukiman}

Kebutuhan ruang untuk tempat tinggal merupakan kebutuhan dasar manusia. Peningkatan jumlah penduduk mengakibatkan kebutuhan akan lahan meningkat. Namun keterbatasan lahan di Kota Manado menyebabkan timbulnya pemukimanpemukiman padat penduduk diantaranya pemukiman yang berada di Kelurahan Tumumpa Dua Lingkungan 4. Pemukiman sebagai tempat manusia membangun kehidupannya seharusnya dirancang dengan memperhatikan keseim-bangan antara fisik bangunan, alam, dan manusia sebagai penghuni pemukiman tersebut. Pengelolaan RTH membutuhkan peran aktif pemerintah secara umum dan masyarakat secara khusus. Keterlibatan masyarakat dalam pembangunan RTH, diharapkan dapat menumbuhkan rasa kepedulian terhadap lingkung- an, sehingga eksistensi RTH dapat tetap terjaga dan upaya untuk membangun kota hijau (green city) yang berwawasan lingkungan dapat tercapai (Moniaga, I 2015).

Ruang Terbuka Hijau (RTH) merupakan ruang terbuka publik yang berfungsi sebagai ruang sosial tempat masyarakat berkumpul, bercengkrama dan berinteraksi satu dengan lainnya, pembentuk iklim kota, menjaga ketersediaan air tanah dan juga sebagai greenbelt (sabuk pengaman) area pantai dan sungai. Manfaat RTH antara lain menyeimbangkan kualitas lingkungan sekitar dengan menciptakan elemen-elemen tanaman sebagai unsur pembentuk iklim mikro atau kenyamanan lingkungan pemukiman.

Peran masyarakat dalam penyediaan dan pemanfaatan RTH merupakan upaya melibatkan masyarakat baik pada tahap perencanaan, pemanfaaatan dan pengendalian. Peran masyarakat pada RTH privat meliputi : a) memberikan penyuluhan tentang peranan RTH dalam peningkatan kualitas lingkungan, b) turut serta dalam meningkatkan kualitas di permukiman dalam hal penanaman tanaman, dan pengelolaan sampah, c) mengisi seoptimal mungkin lahan pekarangan dan lahan kosong dengan berbagai jenis tanaman, baik ditanam langsung maupun ditanam dalam pot, d) turut serta secara aktif dalam komunitas masyarakat pencinta RTH.

Kondisi RTH pada lokasi IbM terdapat pada lokasi tempat pemakaman umum (TPU) yang merupakan salah satu 
ruang terbuka publik dengan fungsi sebagai RTH karena terdapat tanaman-tanaman sebagai elemen pelengkap RTH baik pohon, perdu, dan semak. Fungsi TPU selain sebagai tempat penguburan jenasah juga memiliki fungsi ekologis yaitu sebagai daerah resapan air, tempat pertumbuhan berbagai jenis vegetasi, pencipta iklim mikro, serta tempat hidup burung serta fungsi sosial masyarakat disekitar seperti beristirahat. (Permen PU No 5/Tahun 2008 tentang Pedoman Penyediaan dan Pemanfaatan Ruang Terbuka Hijau di Kawasan Perkotaan).

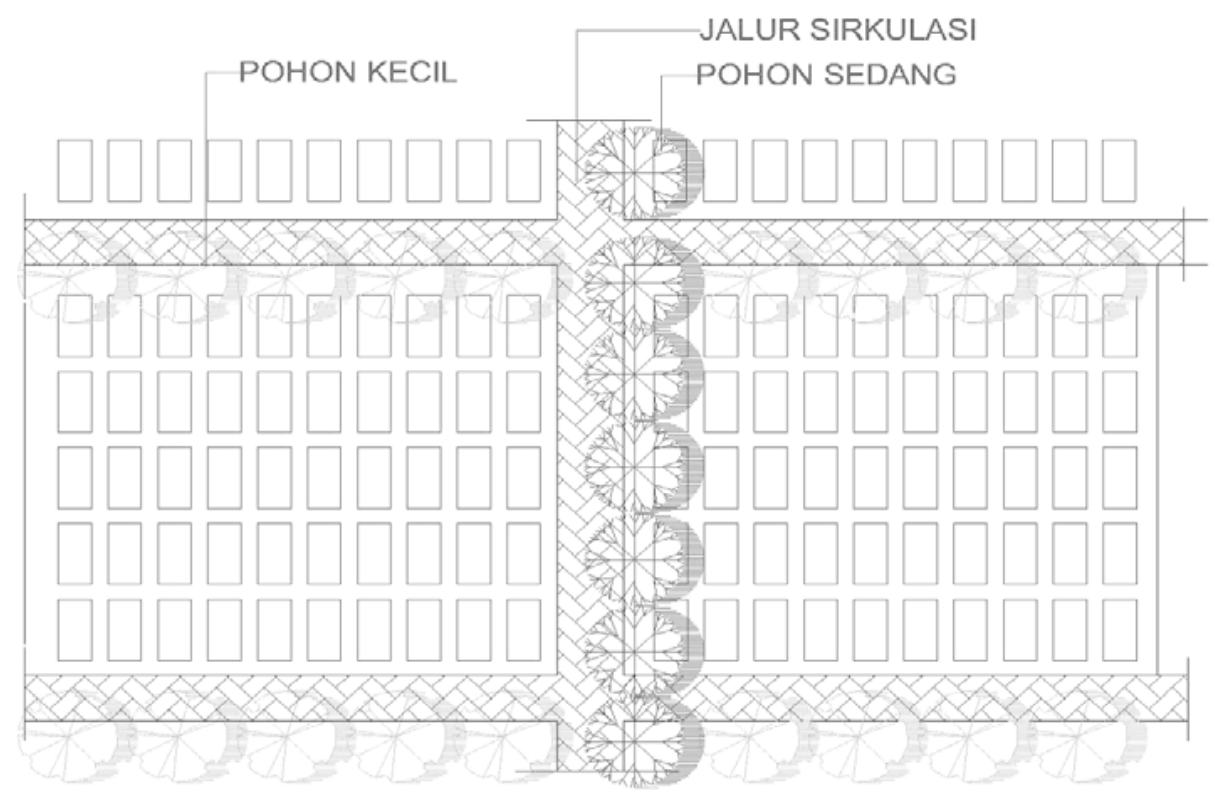

Gambar 2. Contoh Pola Penanaman Pada RTH Pemakaman

( Sumber: Permen PU No 5/Tahun 2008 tentang Pedoman Penyediaan dan Pemanfaatan Ruang Terbuka Hijau di Kawasan Perkotaan)
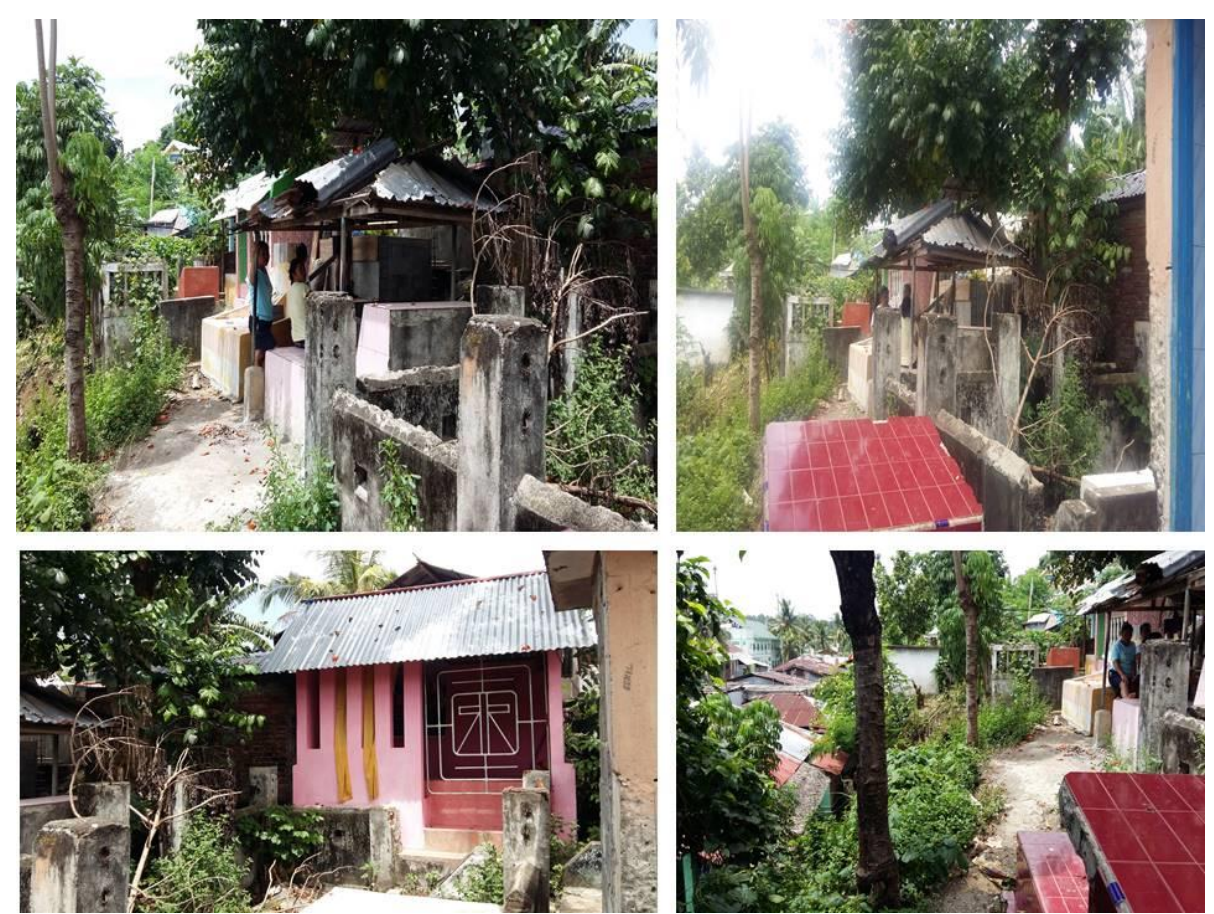

Gambar 3. RTH Pemakaman di Lingkungan 4 Kelurahan Tumumpa Dua 
HASIL DAN PEMBAHASAN

Pembangunan IPAL dan Peran Masyarakat dalam Partisipasi

\section{Pembuatan Taman IPAL Komunal}

Pengembangan Instalasi Pengelolaan Air Limbah (IPAL) Komunal di lingkungan permukiman padat penduduk Kelurahan Tumumpa Dua merupakan suatu sistem terintegrasi pemanfaatan ruang sempadan sungai untuk sarana sanitasi dan ruang terbuka hijau. Lokasi pembangunan IPAL Komunal bertujuan untuk meningkatkan kualitas lingkungan permukiman masyarakat dan pengelolaan sungai. Hal tersebut karena kondisi hunian yang berada di bantaran sungai Bailang telah berada di badan-badan air, sehingga sistem sanitasi masyarakat yang buruk melalui limbah rumah tangga, akan berdampak pada pencemaran air sungai dan dapat menurunkan kualitas lingkungan sekitar hunian.
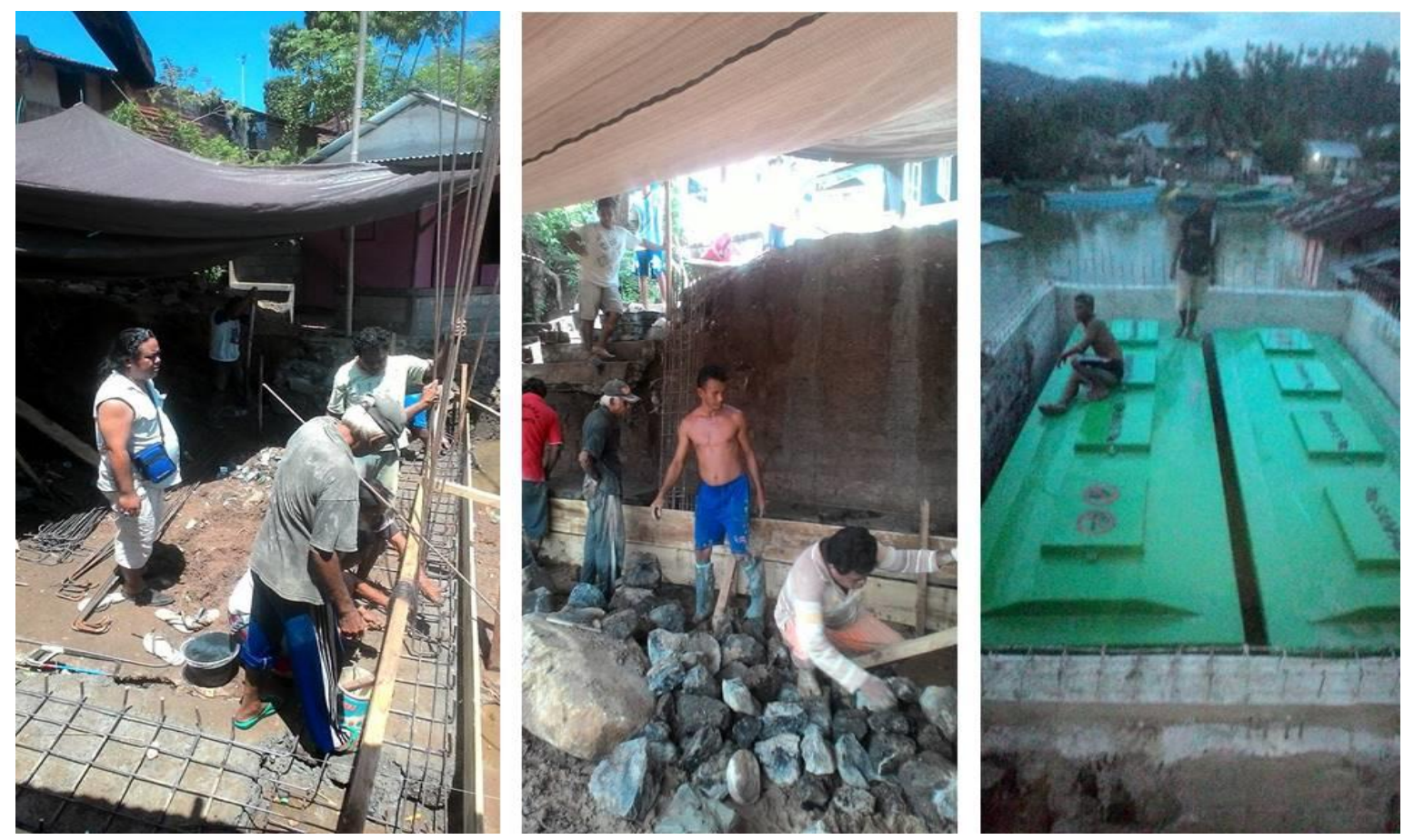

Gambar 4. Kegiatan Pemberdayaan Masyarakat Dalam Pembangunan IPAL Komunal Kelurahan Tumumpa Dua Lingkungan 4 Kota Manado

Kondisi keterbatasan lahan di lokasi kelurahan Tumumpa Dua merupakan suatu tantangan dalam penyediaan IPAL dan ruang publik (RTH). Namun kesediaan salah satu warga masyarakat di lokasi tersebut untuk memberikan lahan yang dimilikinya merupakan solusi pembangunan IPAL dilaksanakan. Gagasan yang diusulkan narasumber dalam kegiatan IbM ini yakni, mengintegrasikan sarana pengolahan sanitasi (IPAL) dengan ruang terbuka publik yang berfungsi sebagai RTH, hal ini bertujuan untuk mencapai efektivitas dalam penyediaan lahan. Fungsi RTH pada lokasi yakni sebagai pembentuk ruang estetika yang dicapai melalui penataan tanamantanaman dalam pot, sebagai ruang sosial yang membentuk nilai-nilai keakraban dan 
kekeluargaan, tempat bermain anak, ruang berkumpul warga pada waktu-waktu tertentu dan sebagai ruang ekologi yang dapat menciptakan iklim sejuk di sekitar lingkungan (iklim mikro). Sehingga tujuan dan manfaat ruang publik di permukiman dapat tercapai melalui sistem integrasi kedua hal tersebut yakni IPAL Komunal dan RTH.

\section{Manfaat Pembinaan dan}

\section{Pendampingan Dalam Pengabdian}

\section{Masyarakat}

Setelah peserta kelompok mitra mengikuti kegiatan penyuluhan ini maka respon yang ditunjukkan diantaranya: masyarakat mengetahui fungsi dan manfaat RTH penting diwujudkan di lingkungan permukiman untuk menciptakan iklim mikro dan tata hijau yang sejuk. RTH di Kelurahan Tumumpa Dua yakni berupa taman pemakaman umum (TPU) yang berfungsi selain sebagai tempat pemakaman juga digunakan masyarakat sebagai tempat bersantai dan duduk-duduk, karena ruang terbuka yang tersedia pada lokasi tersebut hanya pada lokasi TPU. Kelompok masyarakat yang hadir dalam kegiatan IbM ini antara lain mewakili kelompok Karang Taruna, Kelompok Nelayan, dan kelompok Ibu Rumah Tangga. Kelompok Karang Taruna Kelurahan Tumumpa Dua merupakan kelompok aktif yang mengusahakan program-program berbasis pemberdayaan masyarakat. Usulan program yang berhasil dilakukan yakni pembangunan IPAL. Tujuan kegiatan ini diantaranya pembangunan Instalasi Pengelolaan Air Limbah Rumah Tangga sehingga sistem sanitasi lingkungan semakin bersih dan tertata indah.

Hasil Diskusi narasumber dan peserta kegiatan Penyuluhan berlangsung baik dan mencapai sasaran kegiatan. Permasalahan mitra dapat dijawab oleh narasumber dengan menfasilitasi kebutuhan-kebutuhan pengembangan RTH melalui bantuan teknis desain Taman IPAL yang terletak di bantaran sungai Bailang Kota Manado. Manfaat pembinaan dan pendampingan dalam kegiatan pengabdian kepada masyarakat menciptakan kemitraan antara perguruan tinggi dan kelompok masyarakat dalam penyebaran ilmu dan pengetahuan dan peningkatan sumberdaya manusia dalam pembangunan di lingkungan perkotaan.

\section{KESIMPULAN DAN SARAN}

\section{Kesimpulan}

Pemberdayaan masyarakat dalam upaya peningkatan kualitas lingkungan merupakan metode yang tepat dalam mencapai program sanitasi dan ruang 
publik perkotaan. Kegiatan-kegiatan sosialisasi berupa penyuluhan dan pelatihan tentang pengembangan RTH di lingkungan permukiman dan IPAL Komunal merupakan salah satu kegiatan yang dapat menunjang program pemerintah Kota Manado mewujudkan pemberdayaan berbasis lingkungan (PBL-Mapalus) diantaranya pembangunan ruang RTH dan RTNH.

\section{Saran}

a. Pemerintah Kota Manado perlu bekerjasama dan bermitra dengan perguruan tinggi Unsrat, melalui kegiatan tridharma dosen khususnya bidang pengabdian kepada masyarakat untuk mensosialisasikan programprogram pemerintah yang terkait dengan pemberdayaan berbasis lingkungan (PBL-Mapalus); dan

b. Topik-topik kegiatan pengabdian kepada masyarakat (PPM) berbasis pengembangan wilayah kota perlu dikoordinasikan antara Pemerintah, Perguruan Tinggi, dan Masyarakat.

\section{KEPUSTAKAAN}

Anita, J dkk. 2012. Kajian Terhadap Ruang Publik Sebagai Sarana Interaksi Warga di Kampung Muararajeun Lama, Bandung. Jurnal Teknik Arsitektur Itenas. Vol 1 No 1 hal 3-12.

Darmawan. 2009. Ruang Publik Dalam Arsitektur Kota. Universitas Diponegoro. 205 hal.

Ruhaida \& Sunarti. 2012. Pemberdayaan Masyarakat Dalam Peningkatan Permukiman Kumuh Pada Kegiatan PNPM di Kelurahan Muarareja Kota Tegal. Jurnal Teknik PWK 2012. Vol 1 No 1. Hal 48-56

Moniaga, I. 2015. Makalah Pengembangan Ruang Terbuka Hijau dipresentasikan kepada Masyarakat Kelurahan Bitungkarangria Kota Manado. November 2015.

Permen PU No 5/Tahun 2008 tentang Pedoman Penyediaan dan Pemanfaatan Ruang Terbuka Hijau di Kawasan Perkotaan.

Ulya, A \& Marsono, B.Dj. 2014. Perencanaan SPAL dan IPAL Komunal di Kabupaten Ngawi (Studi Kasus Perumahan Karangtengah Prandon, Perumahan Karangasri dan Kelurahan Karangtengah). Jurnal Teknik Pomits. Vol 3 No 2 ISSN: 2337-3539 hal 157161. 